\title{
Pengalaman Lansia dalam Melakukan Personal Hygiene di Lingkungan Banjar Lebih Duur Kaje Gianyar
}

\author{
I Komang Ranandika ${ }^{1}$, Ni Komang Sukraandini ${ }^{2}$, Ni Luh Gede Puspita Yanti ${ }^{3}$ \\ ${ }^{1-3}$ Sekolah Tinggi Ilmu Kesehatan Wira Medika Bali \\ Email:Ranandika19@gmail.com
}

Submitted : 06/02/2020

Accepted: $13 / 02 / 2020$

Published: 14/03/2020

\begin{abstract}
Health problems in the elderly were commonly caused by their gradual physiological changes. These physiological changes decrease their ability in doing their activity in daily living, one of them is personal hygiene. This study aimed to know the elderlies' experience in conducting personal hygiene in Banjar Duur Kaje Gianyar. This was a qualitative study using a descriptive phenomenology approach done in 2019. Four elderlies who met the inclusion criteria involved in this study. Interview and field notes were used to obtain the data. The data analysis using Colaizzi Method showed that there were four main themes on this study: (1) personal hygiene done by maintaining a healthy and clean body, (2) personal hygiene technique to keep the body clean: bathing, teeth brushing and using clean clothes, (3) hindrances in conducting personal hygiene, namely physiological factor and family support, and (4) overcoming those hindrances by doing personal hygiene according to the individual ability. We suggest the health care facilities and participant's families providing adequate physiological and psychological support for the elderly in conducting personal hygiene.
\end{abstract}

Keywords: personal hygiene, elderly, experience

\begin{abstract}
Abstrak
Permasalahan yang timbul pada lansia disebabkan oleh perubahan fisiologis secara bertahap. Perubahan fisik yang terjadi pada lansia tentunya akan mempengaruhi kemandirian lansia terutama kemandirian dalam melakukan personal hygiene. Tujuan penelitian ini untuk mengetahui gambaran pengalaman lansia dalam melakukan personal hygienedi Lingkungan Banjar Duur Kaje Gianyar. Metode penelitian ini adalah penelitian kualitatif dengan pendekatan fenomenologi deskriftif. Penelitian ini dilakukan pada tahun 2019 dengan jumlah sampel 4 orang partisipan. Pengambilan dilakukan dengan metode wawancara dan mengunakan catatan lapangan dan dilakukan analisis menggunakan metode colaizzi. Penelitian ini menghasilkan 4 tema yaitu (1) Pemahaman partisipan tentang melakukan personal hygiene dengan menjaga tubuh tetap sehat dan bersih, (2) Cara melakukan personal hygienedengan menjaga tubuh tetap bersih seperti mandi, menggosok gigi, dan memakai pakian bersih, (3) Hambatannya partisipan dalam melakukan personal hygiene yaitu faktor fisik dan support keluarga, (4) Mengatasi hambatan dalam personal hygiene dengan membersihkan diri sesuai kenyamanan dalam melakukan personal hygiene. Berdasarkan hasil tersebut disarankan agar ada dukungan fisik ataupun psikis terhadap lansia dalam melakukan personal hygiene.
\end{abstract}

Kata kunci : Lansia, Pengalaman, Personal hygiene

\section{PENDAHULUAN}

Peningkatan jumlah penduduk lansia (lanjut usia) pada dasarnya merupakan dampak positif dari derajat kesehatan masyarakat. Peningkatan kesejahteraan baik fisik maupun psikis akan meningkatkan usia harapan hidup lansia. Peningkatan usia harapan hidup mengindikasikan jumlah penduduk lanjut usia (lansia) dari tahun ke tahun semakin meningkat sehingga membawa pengaruh besar dalam pengelolaan masalah kesehatannya (Koswara, 2015).

Jumlah lansia di dunia pada tahun 2013-2050, akan menduduki peringkat teratas dibandingkan dari golongan usia di 
bawahnya yaitu $13,4 \%$ pada tahun 2015 dan $25,3 \%$ pada tahun 2016(World Health Organization, 2015). Pertambahan penduduk lansia di Indonesia menunjukan adanya kecenderungan peningkatan jumlah lansia, pada tahun 2016 pertambahan lansia sebanyak 21,4\% (Kemenkes RI, 2016). Penduduk lansia terbanyak di Indonesia yaitu provinsi Daerah Istimewa Yogyakarta $13,04 \%$, sedangkan di posisi kedua yaitu Jawa Timur 10,4\%, Jawa Tengah 10,34\% dan Bali berada di posisi keempat yaitu sebanyak 9,78\% (BPS, 2017). Jumlah penduduk lanjut usia di Provinsi Bali tahun 2016 sebanyak 462.822 jiwa. Jumlah penduduk lanjut usia tertinggi pertama berada di Kabupaten Gianyar sebesar 86.061 jiwa, dilanjutkan oleh Kabupaten Badung dengan jumlah lansia sebesar 78.170 jiwa, dan Kabupaten Tabanan sebesar 73.778 jiwa, 32.197 jiwa dan Kabupaten Bangli sebesar 22.777 jiwa, serta Kota Madya Denpasar sebesar 14.845 jiwa (Dinas Kesehatan Provinsi Bali, 2018). Berdasarkan data Dinas Kesehatan Kabupaten Gianyar (2018) jumlah penduduk lansia di Kabupaten Gianyar sebanyak 86.061 lansia. Kabupaten Gianyar mempunyai 13 puskesmas, dimana dari 13 puskesmas jumlah lansia terbanyak ada di wilayah UPT Kesmas Gianyar 1 dengan jumlah 5.435 lansia.

Permasalahan yang timbul pada lansia disebabkan oleh perubahan fisiologis secara bertahap. Masalah kesehatan yang sering terjadi pada lansia sering disebut dengan istilah $14 \mathrm{I}$, yaitu immobility, instability, incontinence, intellectual impairment, infection, impairment of vision and hearing, taste,smell, communication, convalescence, skin integrity, impaction, isolation, inanition, impecunity, iatrogenesi, Insomnia, immunedeficiency, impotence(Siburian, 2016).

Perubahan fisik yang terjadi pada lansia tentunya akan mempengaruhi kemandirian lansia. Menurut Atut (2013) Kemandirian adalah kebebasan untuk bertindak, tidak tergantung pada orang lain, tidak terpengaruh pada orang lain dan bebas mengatur diri sendiri atau aktivitas seseorang baik individu maupun kelompok dari berbagai kesehatan atau penyakit. Kemandirian pada lansia sangat penting untuk merawat dirinya sendiri dalam memenuhi kebutuhan dasar manusia (Rohaedi, Putri and Karimah, 2016). Kemandirian dalam mengurus diri sendiri pada lansia dapat dinilai dari kemampuannya dalam melakukan aktivitas sehari-hari seperti mandi, berpakaian rapi, pergi ke toilet, dan melakukan kerbersihan diri (Lopes, Mudayati and Candrawati, 2018).

Kebersihan diri sangat menentukan status kesehatan, dimana individu secara sadar dan atas inisiatif pribadi menjaga kesehatan dan mencegah terjadinya penyakit. Upaya ini lebih menguntungkan bagi individu karena lebih hemat biaya, tenaga, dan waktu dalam mewujudkan kesejahteraan dan kesehatan. Solusi yang bisa dilakukan agar lansia mampu menjaga kebersihan diri salah satunya dengan memberikan motivasi pada lansia agar lansia yang kurang memiliki kemauan dalam melakukan kebersihan diri menjadi berkenan melakukan kebersihan diri dengan cara mengajak lansia untuk aktif dalam merawat dirinya yang meliputi kebersihan badan seperti mandi, mencuci rambut, dan menggosok gigi bagi lansia (Tarwoto. and Wartonah., 2010). Permasalahan yang bisa timbul bila kurangnya kebersihan diri yaitu rentan terhadap penyakit karena kuman-kuman menumpuk di badan yang merupakan sumber penyakit dan kurang percaya diri akibat timbul bau badan yang menyengat dari metabolisme kuman (Muhith and Siyoto, 2016).

Berdasarkan studi pendahuluan yang dilakukan pada tanggal 6 Agustus 2019 di UPT Kesmas Gianyar 1 didapat data yaitu wilayah kerja UPT Kesmas Gianyar 1 mempunyai 10 wilayah kerja 
yaitu Desa Gianyar, Desa Samplangan, Desa Sidan, Desa Tulikup, Desa Temesi, Desa Beng, Desa Tegal Tugul, Desa Abianbase, Desa Serongga, dan Desa Lebih. Menurut data di UPT Kesmas Gianyar 1 terdapat desa dengan personal hygiene yang kurang yaitu Desa Lebih Banjar Lebih Duur Kaje dengan 182 lansia.

Berdasarkan hasil wawancara secara singkat dengan dua lansia mengenai personal hygienedi wilayah kerja UPT Kesmas Gianyar 1 yaitu yang pertama,dengan inisial Ny. G mengatakan biasa mandi 1 kali sehari karena cuacanya dingin takut keram jika mandi 2 kali sehari, dan menyikat gigi sekali. Yang kedua, dengan inisial Tn. S mengatakan hanya mandi satu kali sehari dan bisa tidak mandi hanya lap basah saja karena cuaca dingin, jarang sikat gigi karena sering lupa dan ganti baju jika terlihat kotor saja.

Berdasarkan uraian diatas, maka dari itu peneliti sangat tertarik untuk melakukan penelitian tentang "pengalaman lansia dalam melakukan Personal Hygienedi lingkungan Banjar Lebih Duur Kaje Gianyar”.

\section{METODE PENELITIAN}

Metode penelitian ini adalah penelitian kualitatif dengan pendekatan fenomenologi deskriftif, dengan fokus penelitian adalah lansia dalam melakukan personal hygiene. Empat partisipan dipilih berdasarkan metode purposive sampling dengan kriteria Lansia yang mempunyai lingkungan yang sama, Lansia yang mempunyai kategori old yaitu dari umur 75-90 tahun, Lansia mampu berkomunikasi secara kooperatif dalam mengungkapkan pengalamannya, Lansia yang bersedia menjadi partisipan. Penelitian ini dilakukan di Lingkungan Banjar Lebih Duur Kaje Gianyar. Pengumpulan data yang digunakan pada penelitian ini adalah wawancara mendalam, dan catatan lapangan (field note). Pada penelitian ini semua partisipan sudah mendapatkan penjelasan terlebih dahulu tentang penelitian, prosedur penelitian dan hak-hak partisipan dengan menandatangani inform consent. Analisa data dilakukan dengan Collaizi 7 step proses.

\section{HASIL DAN PEMBAHASAN}

\section{Hasil}

Berdasarkan hasil wawancara yang dilakukan dari 4 partisipan didapatkan 4 tema beserta sub tema yang menunjukan pengalaman lansia dalam melakukan personal hygiene di Lingkungan Banjar Lebih Duur Kaje Gianyar sebagai berikut.

1) Pemahaman partisipan tentang personal hygiene

Pemahaman lansia tentang melakukan personal hygiene adalah upaya memelihara kebersihan diri untuk menjaga tubuh tetap sehat dan bersih. Dari pemaparan diatas terdapat 2 sub-tema dari pemahaman lansia dalam melakukan personal hygiene sebagai berikut.

a) Partisipan menggambarkan pemahaman tentang melakukan personal hygiene yaitu sehat. Laporan hasil penelitian seperti dijelaskan berikut.

"Kita harus menjaga kebersihan diri, supaya kita sehat terhindar dari penyakit dengan caramandi, seperti saya bilang tadi memotong kuku, sebelum makan mencuci tangan, sikat gigi setelah makan atau pada saat mandi, mengganti pakaian jika baju kotor"

(P3 L13-L19)

b) Partisipan menggambarkan pemahaman tentang melakukan personal hygiene yaitu bersih. Laporan hasil penelitian seperti dijelaskan berikut.

"Kebersihan itu ya kita memeliharakebersihan diri seperti mandi, keramas, ganti pakian dan biar tidak bau saja gus, ya biar tidak baukan terpenting gus (tersenyum)". (P1 L16-L20)

2) Cara melakukan personal hygiene 
Cara lansia tentang melakukan personal hygiene adalah dengan menjaga tubuh tetap bersih seperti mandi, menggosok gigi dan menganti pakaian. Dari pemaparan diatas terdapat 1 sub-tema dari pemahaman lansia dalam melakukan personal hygiene sebagai berikut

a) Partisipan menggambarkancara lansia tentang melakukan personal hygiene adalah dengan menjaga tubuh tetap bersih. Laporan hasil penelitian seperti dijelaskan berikut.

"Menjaga kebersihan seperti mandi, gantai pakaian sikat gigi seperti itu dan saya melakukannya sendiri gus"

( L23-30)

3) Hambatannya partisipan dalam melakukan personal hygiene

Partisipan menjelaskan

hambatannya dalam melakukan personal hygieneyaitu fisik, dan support keluarga. Dari pemaparan diatas terdapat 2 sub-tema dari pemahaman lansia dalam melakukan personal hygiene sebagai berikut

a) Partisipan

menggambarkanhambatannya dalam melakukan personal hygieneyaitu faktor fisik. Laporan hasil penelitian seperti dijelaskan berikut.

"Kamar mandi saya kan di belakang rumah, kadang cuaca dingin jika saya masak air hangat saya susah mengangkatnya agak licin takut jatuh, kalau terus minta bantuan ya saya juga sungkan"

(P1 L45-50)

b) Partisipan

menggambarkanhambatannya dalam melakukan personal hygieneyaitu support keluarga. Laporan hasil penelitian seperti dijelaskan berikut.

“..Saya orangnya rapi, kalau rambut saya sudah terlihat panjang saya ingin ke tukang cukur tapi kendala saya tidak ada yang mengantar karna cukup jauh jarak dari rumah"
(P3 L27-31)

4) Cara mengatasi hambatan dalam personal hygiene

Partisipan menjelaskan cara mengatasi hambatannya yaitu mebersihkan diri sesuai kenyamanandalam melakukan personal hygiene .Dari pemaparan diatas terdapat 1 sub-tema dari pemahaman lansia dalam melakukan personal hygiene sebagai berikut.

a) Partisipan menggambarkancara mengatasi hambatannya yaitu membersihkan diri sesuai kenyamanandalam melakukan personal hygiene. Laporan hasil penelitian seperti dijelaskan berikut.

"Pernah dulu, saya mintak dibuatin air hangat pada anak saya untuk mengatasi kedinginan saat mandi, karena terlalu sering, saya merasa tidak enak untuk dibuatin air hangat. Makanya saya mandi di siang hari biar tidak merasa kedingininan saat mandi" (L45-52)

\section{Pembahasan}

Hasil penelitian ini sejalan dengan hasil penelitian sebelumnya yang menyatakan bahwa semakin tinggi tingkat pengetahuan lansia dalam melakukan personal hygine, maka akan semakin baik pemenuhan personal hygine pada lansia tersebut, begitu pula sebaliknya. Dengan demikian, dibutuhkan tingkat pengetahuan yang tinggi agar lansia dalam berperilaku menerapkan personal hygine dapat dilakukan secara baik dan benar(Safitri, Marjulita and Andika, 2016).

Hasil penelitian ini sejalan dengan penelitian sebelumnya yang mengungkapkan bahwa perilaku lansia dalam pemenuhan personal hygiene yang baik, menunjukkan lansia dapatmelakukan aktivitas sehari-hari seperti perawatan kuku kaki dan tangan, perawatankulit kepala dan rambut, perawatan mata, hidung dan telinga, perawatan gigi, dan genetalia 
(Yulaikhah, Arisdiani and Widiastuti, 2017).

Hasil penelitian ini sejalan dengan penelitian sebelumnya yang menyatakan bahwa dukungan keluarga dengan kategori baik maka perawatan diri lansia yang dilakukan hasilnya akan lebih baik dibandingkan dengan orang yang tidak mempunyai dukungan keluarga agar dapat meningkatkan kesehatan lansia (Alfiaturrohmah, Anggraeni and Jati, 2018).

Hasil penelitian ini sejalan dengan hasil penelitian sebelumnya yang menyatakan bahwa faktor yang mempengaruhi personal hygiene lansia yaitu faktor fisik dan faktor lingkungan(Hardono et al, 2019).

Hasil penelitian ini sejalan dengan penelitian sebelumnya yang menyatakan bahwa pemeliharaan personal hygine pada lansia sangat diperlukan untuk kenyamanan, keamanan dan kesehatan lansia tersebut. Lansia yang sehat mampu memenuhi kebutuhan perawatan personal hygine sendiri, namun sebaliknya apabila lansia tersebut mengalami gangguan kondisi fisik dikarenakan oleh penyakit tertentu maka diperlukan bantuan untuk melakukan perawatan personal hygine secara rutin (Safitri, Marjulita and Andika, 2016).

Personal hygiene adalah suatu tindakan untuk memelihara kebersihan dan kesehatan seseorang untuk kesejaterahan fisik dan psikis(Muhith and Siyoto, 2016). Menurut Depkes (2000) perawatan diri adalah salah satu kemampuan dasar manusia dalam memenuhi kebutuhan guna mempertahankan kehidupannya, kesehatan, kesejaterahan, sesuai dengan kondisi kesehatan. Klien dinyatakan terganggu keperawatan dirinya jika tidak dapat melakukan perawatan diri (Muhith and Siyoto, 2016).

$$
\text { Menurut Depkes }
$$
menyatakan bahwa pengetahuan tentang higiene akan memengaruhí praktik higiene seseorang. Namun, hal ini saja tidak cukup, karena motivasi merupakan kunci penting dalam pelaksanaan hygiene tersebut. Permasalahan yang sering terjadi adalah ketiadaan motivasi karena kurangnya pengetahuan(Muhith and Siyoto, 2016).

Menurut Maryam (2008) keluarga merupakan Support System utama bagi lanjut usia dalam mempertahankan kesehatannya, peranan keluarga dalam perawatan lanjut usia diantaranya merawat dan menjaga lanjut usia, mempertahankan dan meningkatkan status mental, mengantisipasi perubahan social ekonomi serta memberikan motivasi dan memfasilitasi kebutuhan lanjut usia (Alfiaturrohmah, Anggraeni and Jati, 2018) Menurut Hidayat (2010) menjaga kebersihan diri atau Personal hygienedilaksanakan dengan menjaga kebersihan tubuh, yang dapat dilakukan dengan mandi, mengosok gigi, mencuci tangan, dan memakai pakaian yang bersih. Kebersihan dengan cara mandi maka dapat menghilangkan bau, debu, dan sel-sel kulit yang sudah mati. Mandi bermanfaat untuk memelihara kesehatan, menjaga kebersihan, serta menjaga penampilan agar tetap rapi.Sedangkan mencuci tangan dengan sabun dikenal juga sebagai salah satu upaya untuk mencegah penyakit. Hal ini dilakukan karena tangan seringkali menjadi agen yang membawa kuman dan menyebabkan pathogen berpindah dari satu orang ke orang lain, baik kontak langsung maupun tidak langsung (Hardono et al, 2019).

Menurut asumsi peneliti dari hasil wawancara dimana partisipan mengungkapkan kerbersihan diri yaitu menjaga tubuh bersih dan terhindar dari penyakit. Pemahaman partisipan tentang personal hygiene cukup baik, dimana partisipan mengerti pentingnya menjaga kebersihan agar terhindar dari penyakit.

Berdasarkan asumsi peneliti menjaga kebersihan diri atau Personal hygienedilaksanakan dengan menjaga kebersihan tubuh, yang dapat dilakukan 
dengan mandi, mengosok gigi dan memakai pakaian yang bersih. Kebersihan dengan cara mandi, menggosok gigi dan mengganti pakaian yng bersih dapat menghilangkan bau, debu, dan sel-sel kulit yang sudah mati. Dengan menjaga kebersihan diri bermanfaat untuk memelihara kesehatan, menjaga kebersihan, serta menjaga penampilan agar tetap rapi.

Menurut Depkes (2015) beberapa faktor yang mempengaruhi kebutuhan personal hygiene lansia diantaranya yaitu kebiasaan seseorang, dan kondisi fisik dan psikis.Perubahan pada faktor fisik yang terjadi pada lansia tentunya akan mempengaruhi kemandirian lansia. Kemandirian adalah kebebasan untuk bertindak, tidak tergantung pada orang lain, tidak terpengaruh pada orang lain dan bebas mengatur diri sendiri atau aktivitas seseorang baik individu maupun kelompok dari berbagai kesehatan atau penyakit. Kemandirian pada lansia sangat penting untuk merawat dirinya sendiri dalam memenuhi kebutuhan dasar manusia(Rohaedi, Putri and Karimah, 2016). Sedangkan faktor psikis dimana lansia membutuhkan bantuan dalam melakukan personal hygiene.

Menurut Maryam (2008) keluarga merupakan Support System utama bagi lanjut usia dalam mempertahankan kesehatannya, peranan keluarga dalam perawatan lanjut usia diantaranya merawat dan menjaga lanjut usia, mempertahankan dan meningkatkan status mental, mengantisipasi perubahan social ekonomi serta memberikan motivasi dan memfasilitasi kebutuhan lanjut usia (Alfiaturrohmah, Anggraeni and Jati, 2018)

Menurut peneliti, perubahan pada lansia dapat mempengaruhi dalam pemenuhan personal hygiene, terutama pada perubahan fisik. Dimana pada saat kedinginan partisipan enggan melakukan pemenuhan personal hygiene. Namun tidak semua partisipan merasa terganggu dengan cuaca dingin dalam melakukan pemenuhan personal hygiene.

Berdasarkan asumsi peneliti pemeliharaan personal hygine pada lansia sangat diperlukan untuk kenyamanan, keamanan dan kesehatan lansia tersebut. Lansia yang sehat mampu memenuhi kebutuhan perawatan personal hygine sendiri, namun sebaliknya apabila lansia tersebut mengalami gangguan kondisi fisik dikarenakan oleh penyakit tertentu maka diperlukan bantuan untuk melakukan perawatan personal hygine secara rutin.

\section{SIMPULAN}

Berdasarkan hasil penelitian yang telah dilakukan didapatkan fenomenologi pengalaman pengelompokan tema dan formulasi makna serta pernyataan sighnifikasi pengalaman lansia dalam melakukan personal hygiene di lingkungan Banjar Lebih Duur Kaja Gianyar sebagai berikut : Pemahaman partisipan tentang melakukan personal hygiene dengan sub tema yaitu sehat dan bersih, Cara melakukan personal hygiene dengan sub tema yaitu menjaga tubuh tetap bersih seperti mandi, menggosok gigi, dan memakai pakian bersih, Hambatan partisipan dalam melakukan personal hygiene dengan sub tema yaitu faktor fisik dan support keluarga, Cara mengatasi hambatan dalam personal hygiene dengan sub tema yaitu membersihkan diri sesuai kenyamanan dengan personal hygiene.

Bagi perawat gerontik diharapkan dapat memberikan asuhan keperawatan terkait pemenuhan personal hygiene pada lansia perawat gerontik dapat menggunakan pengalaman lansia sebagai acuan dalam memberikan asuhan keperawatan pada lansia. Bagi peneliti selanjutnya diharapkan dapat melakukan penelitian lebih lanjut tentang pengalaman lansia dalam melakukan personal hygiene.

\section{DAFTAR PUSTAKA}

Alfiaturrohmah, S. N., Anggraeni, R. and 
Jati, R. P. (2018) 'Hubungan Peran Family Caregiver Terhadap Pemenuhan Personal Hygiene Lansia', Jurnal Keperawatan, 10(2), pp. 147-152.

BPS (2017) 'Profil Statistik Kesehatan 2016', Profil Statistik Kesehatan.

Hardono et al (2019) 'Faktor-faktor yang mempengaruhi pemenuhan personal hygiene pada lansia', Issn, 1(February), pp. 29-40.

Kemenkes RI (2016) Buletin Gambaran Kesehatan Lanjut Usia di Indonesia, data dan informasi kesehatan. jakarta. Available at: www.depkes.go,id/download/buletinl ansiapdf.

Koswara (2015) 'psikologi usia'. Available at: http://www.epsikologi/usia/2.html.

Lopes, O. R. D. F., Mudayati, S. and Candrawati, E. (2018) 'Hubungan Pengetahuan Tentang Kebersihan Diri Dengan Tingkat Kemandirian Melakukan Aktivitas Personal Hygiene Lansia', Nursing News: Jurnal Ilmiah Keperawatan, 3(1).

Muhith, A. and Siyoto, S. (2016) Pendidikan Keperwatan Gerontik. yogyakarta: CV Andi Offset.

Rohaedi, S., Putri, S. T. and Karimah, A. D. (2016) 'Tingkat Kemandirian Lansia Dalam Activities Daily', Pendidikan Keperawatan Indonesia.

Safitri, F., Marjulita, A. and Andika, F. (2016) 'Hubungan pengetahuan , Dukungan Keluarga dan Kondisi Fisik dengan Personal Hygine pada Lansia Di UPTD Rumoh Sejahtera Geunaseh Sayang Ulee Kareng Kota Banda Aceh Relationship between Knowledge , Family Support and Physical Condition with Personal
Hygiene', Journal of Healthcare Technology and Medicine, 2(2), pp. 162-170.

Siburian, P. (2016) 'Bagaimana memberdayakan kemampuan fisik lansia?(serial online)', Dari: URL: http://www. waspada. co. id/html. Diakses, 24.

Tarwoto. and Wartonah. (2010) Kebutuhan Dasar Manusia dan proses keperawatan. jakartal: salemba medika.

World Health Organization (2015) WHO Global Report on Falls Prevention in older Age. perancis: WHO.

Yulaikhah, D., Arisdiani, T. and Widiastuti, Y. P. (2017) 'Perilaku Personal Hygiene Lanjut Usia', Jurnal Keperawatan, 9(2), pp. 44-51. 